\title{
THE COMPLEXITY (WITH)IN CREATIVITY: FINDING NEW PATHS FOR EDUCATION
}

Data de aceite: 01/12/2021

Data de submissão: 24/09/2021

\section{Andreia Valquaresma}

Faculty of Psychology and Education Sciences, University of Porto, Portugal https://orcid.org/0000-0002-5803-9413

\section{Joaquim Luís Coimbra}

Faculty of Psychology and Education Sciences,

University of Porto, Portugal https://orcid.org/0000-0001-8755-5698
ABSTRACT: Contemporary living frequently involves being faced with uncertainty. With the technological revolution quickening the pace of our lives, the educational realm has been increasingly confronted with demands for innovative pedagogical approaches. In this framing creativity arises as one of the key constructs in education, being often envisioned as a synonymous with the ability to successfully overcome the unexpected. Nevertheless, it is often portrayed from a static and functionalist perspective that seems unable to give account of the construct's multidimensional, dynamic, and socioculturally-situated features. In this chapter, we address some of the impending challenges of contemporary education by suggesting a new outlook on creativity, in which it emerges as an inherent attribute of complex sociocognitive structures. Acknowledging that creative-like experiences can unfold new possibilities for human sociocognitive development across the lifespan, we suggest that they can shape one's sense of agency and have a significant impact on the process of individuation, which is critical in facing uncertainty, incoherence, and contradiction in complex, ambiguous and increasingly demanding societies. Moreover, we argue that creativity, especially in educational settings, must be envisioned as embedded in a complexity matrix that entails diversified and challenging contexts to be able to nurture creative potential throughout the lifespan.

KEYWORDS: Creativity, Education, Uncertainty, Complexity, Sociocognitive development, Lifespan perspective.

\section{A COMPLEXIDADE NA CRIATIVIDADE: DESCOBRINDO NOVOS CAMINHOS PARA A EDUCAÇÃO}

RESUMO: Viver na contemporaneidade frequentemente envolve depararmo-nos com a incerteza. Com a revolução tecnológica a acelerar o ritmo das nossas vidas, o reino da educação tem sido, cada vez mais, confrontado com demandas de abordagens pedagógicas inovadoras. Nesse enquadramento, a criatividade surge como um dos constructos-chave na educação, sendo, frequentemente, encarada como sinónimo da capacidade de enfrentarmos o inesperado com sucesso. No entanto, muitas vezes, é retratada a partir de uma perspetiva estática e funcionalista que parece incapaz de reconhecer a essência multidimensional, dinâmica e socioculturalmente situada do constructo. Neste capítulo, abordamos alguns dos desafios iminentes da educação contemporânea, sugerindo uma nova perspetiva face à criatividade, na qual esta emerge como um 
atributo inerente a estruturas sociocognitivas complexas. Reconhecendo que as experiências de tipo criativo podem revelar novas possibilidade para o desenvolvimento psicológico ao longo da vida, sugerimos que estas podem moldar o sentido de agência do sujeito psicológico humano e ter um impacto significativo no processo de individuação, que se revela crucial enfrentar a incerteza, a incoerência e a contradição em sociedades complexas, ambíguas e cada vez mais exigentes. Além disso, argumentamos que a criatividade, especialmente em contexto educativos, deve ser encarada como imbuída numa matriz de complexidade que requer contextos diversificados e desafiantes, a fim de promover o potencial criativo ao longo de todo o ciclo de vida.

PALAVRAS-CHAVE: Criatividade, Educação, Incerteza, Complexidade, Desenvolvimento sociocognitivo, Perspetiva do Ciclo Vital.

\section{I INTRODUCTION}

In contemporary society, being, becoming and relating with oneself, others and the world (GOODMAN, 1978) often implies crossing paths with creativity. We live in times of permanent transition and constant connection, where the appeal to creativity is present in every life domain. The multitude of challenges we are faced with, require quick and creative responses. In fact, balancing intra and inter-psychological experience in uncertaintypervaded developmental contexts can turn out to be a quite strenuous task. From a systemic standpoint, the profound societal changes that have been emerging can have an impact not only at the macro but also at the micro-level, potentially altering one's developmental trajectory (BRONFENBRENNER, 1979).

In the process of defining developmental pathways, educational contexts are arguably decisive. Thus, it seems timely to reflect upon the significance of intentionally embedding uncertainty and creativity into educational settings as means to broaden developmental possibilities (BEGHETTO, 2019). Given the intrinsic nature of the relationship between creativity and uncertainty (BEGHETTO, 2020), such might also contribute to unfolding new opportunities for students to express their creative potential. By challenging them to explore the new and the unpredictable in the classroom, they have a chance to experience an agentic sense over their creative actions, which can potentially transfer to diverse life contexts. Educational contexts can, then, have an indelible impact in shaping one's personal, social, and cultural identity, adding unique elements to the discussion concerning the role creativity can play in contemporary society (VALQUARESMA, 2020).

\section{I CREATIVITY IN CONTEMPORARY SOCIETY}

Education has long been regarded as a solid basis for society, functioning as a means of social promotion and integration (BALLANTINE; HAMMACK, 2012). Nowadays, following the tenets of a hyper-industrial society (STIEGLER, 2013), educational settings are permeated by short-term goals and flexibility, potentially risking one's ability to project 
the future and construct new worlds of meaning. A culture of sameness seems to saturate the educational realm (GLĂVEANU, 2018; GLĂVEANU; BEGHETTO, 2017), emphasizing standardization, and narrowing the exploration of knowledge domains to the ones whose outcomes are more easy to quantify. The nefarious consequences of such standards extend from an increased dominance over one's sense of agency to the perils of validating unequal access to diverse developmental possibilities (BAUMAN, 2000). Given that creativity and possibility are so deeply entwined (GLĂVEANU, 2020), the potential consequences for the development of the former should not be disregarded.

\subsection{Creativity and Innovation: two sides of the same coin?}

The wide spreading of the human capital theory in contemporary societies led to increasing investment in lifelong learning. In this framing, competitiveness and productivity are regarded as anchors of social and individual development (FUENTE, 2011), and creativity and innovation become frequently used interchangeably, being often envisioned as two sides of the same coin. Typically ascribed to an intra-individual sphere, both become keysynonymous concepts in worldwide educational and economical systems (SALICETI, 2015; SERDYUKOV, 2017). Yet, by highlight the relevance of individual action without adequately considering the influence of context in the processes of human agency, those discourses might be detrimental. Being continuously faced with uncertainty can produce an ontological risk for the human psychological subject, potentially heightening one's anxiety levels and threatening one's sense of identity. Moreover, it can reduce the capacity to integrate the complexity of diverse life experiences and contexts, narrowing worldmaking abilities. On the other hand, those discourses implicitly support the standardization of educational practices, concealing the multidimensional, dynamic, and challenging nature of creativity ${ }^{1}$.

If we turn the spotlight to education, even though curricular programs and educational goals throughout the world (OECD, 2018; UNESCO, 2016) seem to have hit the jackpot by including creativity in their principles, a closer look unveils a tendency to resort to brief and decontextualized interventions (VALQUARESMA; COIMBRA, 2021a), with low impact on the processes of developmental change (COIMBRA, 1991a; GUIDANO, 1991; KEGAN, 1982).

\subsection{Creativity, Complexity and Education}

The drive for psychological change and development is frequently anchored in dissonance. Dissonance can, in fact, unveil possibilities for the development of creativity (HUANG, 2020). Yet, paradoxically, what we come to observe in our societies, tends to be a search for a single-tone harmony, evidenced in the definition of "one-fits-all" behavioural standards. Such seems to collide with the fact that creativity is entwined with originality and complexity. Within the educational realm, being oblivious to the complexity of creativity (and

1 The challenge dimension is deemed a cardinal principle for the overall sociocognitive and creativity developmental processes (Bandura, 2001; Csikszentmihalyi, 1999; Kaufman \& Beghetto, 2009; Kelly, 1991; Piaget, 1978; Vygotsky, 2004). 
its ability to make complexity blossom) may result in disengaged educational interventions that bear no space for the worldmaking processes able to enlighten sociocognitive and creative development (VALQUARESMA; COIMBRA, 2021b).

In this sense, the guidelines and principles that underpin educational systems should be in tune with an understanding of the underlying complexity of the creative experience. Hence, it seems critical to integrate this complexity-generating creativity in curricula and educational programs (BOCCHI et al., 2014; MONTUORI, 2021), namely through an intentional, unequivocal, and transversal approach that can balance the idiosyncrasies of individual psychological development with the influence of the surrounding context.

Nevertheless, bringing creativity into everyday class can be challenging. Not only does creativity intersects numerous fields of human sociocognitive and emotional functioning (which can jeopardize achieving a coherent understanding of its specificities) but, at the same time, it is intermingled with a variety of environments (of natural and artificial nature). Its multisystemic and dynamic features increase the complexity of defining, implementing, and measuring it. Despite all these hurdles, creativity is, nowadays, framed within the key educational competencies for the 21st century (FINNISH NATIONAL AGENCY FOR EDUCATION, 2017; MINISTRY OF EDUCATION, 2017; OECD, 2020; VINCENT-LACRIN et al., 2019). And if educational systems should focus on preparing students to deal with complex problems that require creativity to be solved (OECD, 2018), education should also advocate for the relevance of educational goals that promote a qualitative outcome. In other words, pursuing educational goals that encourage a critical understanding of the world (through nurturing social perspective-taking, critical thinking, and metacognitive competencies) can expand levels of sociocognitive development whose complexity intertwines with (and fosters) creativity. A first step in tackling the activation of creativity development is to deliberately foster the development of sociocognitive structures, such as social perspective-taking, social problem solving, and social negotiation strategies (COIMBRA, 1991b; COIMBRA et al., 1986; COIMBRA; CAMPOS, 1990). Secondly, promoting the access (and reflecting upon) aesthetically diverse experiences can be essential since it implies becoming familiar with a variety of languages that contribute to the process of worldmaking. Evolving within that diversity is a complexity-inducing experience that has a lasting impact on one's sociocognitive structures, potentially and gradually contributing to their transformation as structures d'ensemble in their very nature.

\subsection{Creativity across the lifespan}

Formal education contexts are increasingly broadening their scope of action, encompassing not only children, adolescents, and young adults, but also late adults and the elderly. In this light, reflecting on creativity in education should involve a life span viewpoint.

An analysis of the ontogenetic processes of development discloses how selfregulation mechanisms can impact the internalization of life experiences (BANDURA, 
1977). Additionally, the intrinsic relationship between creativity and metacognition (JIA; LI; CAO, 2019; KARWOWSKI; CZERWONKA; KAUFMAN, 2020) -and their closeness with self-regulatory mechanisms such as creative identity, creative self-concept, and creative self-efficacy (KARWOWSKI; BARBOT, 2016; KARWOWSKI; LEBUDA; BEGHETTO, 2019) -, accentuates the potential impact creativity can have across the lifespan. Furthermore, given how context can open developmental possibilities (BALTES; LINDENBERGER; STAUDINGER, 2006; GLĂVEANU, 2018), the significance of a complexity-generating creativity -based on possibility thinking (CRAFT, 2002, 2011)- is heightened. Being confronted with complex problem-solving situations that, arguably, imply using creativity, feeds the production of complex responses. The complexity of such psychological creations is expected to enhance as a function of age (even if age is not to be taken as an autonomous developmental variable), highlighting the positive effect of collecting socioculturallycharged experiences (BALTES; STAUDINGER, 1996). Hence, education could benefit from thoroughly exploring the potential for creativity in every stage of life.

The sociocultural perspective on lifespan development has suffered a transformation because of recent changes in the labour world. For a long time, creativity was thought to be a privilege of the young. However, recent research has shown that ageing can provide a variety of opportunities for creative and psychological growth, (JUNG; VARTANIAN, 2018; WEINBERG; GALENSON, 2019). On the other hand, empirical evidence of the association between creativity and well-being has been growing (TANG et al., 2021), supporting the idea that creating a space for creativity in one's life can be a successful strategy to fight the detrimental consequences of the normal ageing process, and embrace it in a positive and meaningful way.

In this regard, educational systems need to acknowledge how important it is to promote creativity across the lifespan and invest in the definition of educational goals that seek to empower students of all ages, helping them gain an agentic sense over their lives. Especially in the aftermath of the COVID-19, education needs to offer students a variety of opportunities and challenges that can, effectively, intermingle moments of exploration and reflection to broaden students' developmental horizons. Following these steps, educational contexts can nurture a solid and positive identity definition, empowering students, regardless of their age, to fight back the anxiogenic de-individuation process that contemporary living seems to entail (STIEGLER, 2005).

\section{I FINAL REMARKS}

We are living in an era where social and cultural changes are multiplying at an alarming rate, with unmistakable consequences for the continuous processes of psychological development. This dissonance has replicated multi-systemically. In this discussion we focused on the educational system. Along these lines, we sought to critically analyse the 
apparent gap between educational goals and outcomes, regarding the developmental role creativity can play in the process of adequately facing the challenges of contemporary life.

In the face of the uncertain, the unpredictable, and the unknown, creativity has been depicted, particularly by the hegemonic and political discourses, as the ultimate tool of hope of success, concealing, we believe, a light and acritical comprehension of a construct endowed with a singular complexity.

Departing from a complexity and developmental matrix for creativity, it becomes clear how it can balance the ontogenetic developmental process with myriad social and cultural influences. In this view, the analysis of the intersection of creativity, education and lifespan psychological development can configure an understanding of creativity as disclosing the complexity of underlying psychological structures. This approach highlights the relevance of considering the definition of educational goals and curricula following a time-conscious axis (VALQUARESMA; COIMBRA, 2021b). In contemporary education, being able to see beyond the short-term can unfold perspectives for the future that foster a transformative creativity, with the potential to impact the whole developmental spheres. Furthermore, worldmaking abilities can be indelibly transformed as well.

At a crossroads, education seems urged to forsake outdated perceptions and hollow perspectives, for the sake of continuing to be regarded as valuable and meaningful for the overall process of human development in the twenty-first century. To that end, creativity might be a fruitful path towards the development of the complexity of human psychological structures, fostering the process of individuation through which the uncertainty of contemporary life can be adequately integrated throughout the lifespan.

\section{REFERENCES}

BALLANTINE, J. H.; HAMMACK, F. M. The sociology of education: a systematic analysis. 7th. ed. Upper Sadle River, New Jersey: Pearson Education Limited, 2012.

BALTES, P. B.; LINDENBERGER, U.; STAUDINGER, U. M. Life Span Theory in Developmental Psychology. In: Handbook of child psychology: Theoretical models of human development. 6th. ed. Hoboken, NJ: John Wiley \& Sons Inc., 2006. v. 1p. 569-664. Disponível em: internalpdf://236.246.16.117/Life_Span_Theory_in_Developmental_Psychology.pdf.

BALTES, P. B.; STAUDINGER, U. M. Interactive Minds. Life-Span perspectives on the social foundation of cognition. Cambridge: Cambridge University Press, 1996.

BANDURA, A. Self-Efficacy: Toward a Unifying Theory of Behavioral Change. Psychological Review, [S. I.], v. 84, n. 2, p. 191-215, 1977. Disponível em: internal-pdf://0437328982/Bandura1977_ SelfEfficacy_Unifying Theory.pdf.

BAUMAN, Z. Liquid Modernity. Cambridge, UK: Polity Press, 2000. 
BEGHETTO, R. A. Structured Uncertainty: How Creativity Thrives Under Constraints and Uncertainty. In: MULLEN, C. A. (org.). Creativity Under Duress in Education? Resistive Theories, Practices, and Actions. Switzerland: Springer, 2019. p. 27-40.

BEGHETTO, R. A. Uncertainty. In: GLAVEĂNU, V. P. (org.). The Palgrave Encyclopedia of the Possible. Switzerland: Springer International Publishing, 2020. p. 1-7. DOI:

https://10.100/978-3-319-98390-5_122-1.

BOCCHI, Gianluca; CIANCI, Eloisa; MONTUORI, A.; TRIGONA, Raffaella; NICOLAUS, Oscar. Educating for creativity. World Futures, [S. I.], v. 70, n. 5-6, p. 336-369, 2014. DOI: 10.1080/02604027.2014.977084.

BRONFENBRENNER, U. The ecology of human development: Experiments by nature and design. [s.I.] : Harvard University Press, 1979.

COIMBRA, J. L. Desenvolvimento de Estruturas Cognitivas da Compreensão e Acção Interpessoal. 1991a. Universidade do Porto, Porto, 1991. Disponível em: https://repositorio-aberto. up.pt/handle/10216/17839.

COIMBRA, J. L. Cognitive-developmental strategies in interpersonal psychological intervention. 1991b. Porto, [S. I.], 1991.

COIMBRA, J. L.; CAMPOS, B. P. Organization of interpersonal experience and organization of interpersonal action-related thought: a décalage in the adolescents interpersonal development. In: VANDENPLAS-HOLPER, C.; CAMPOS, B. P. (org.). Interpersonal and identity development: new directions. Porto: Instituto de Consulta Psicológica Formação e Desenvolvimento, 1990. p. 35-45. Disponível em: https://sigarra.up.pt/fpceup/pt/pub_geral.pub_view?pi_pub_base_id=83013.

COIMBRA, J. L.; SERRA, M.; MAGALHÃES, A.; GUIMARÃES, B.; ALVES, G. Psychological intervention and youth interpersonal development. Cadernos de Consulta Psicológica, [S. I.], v. 2, p. 56-69, 1986. Disponível em: https://sigarra.up.pt/fpceup/pt/pub_geral.pub_view?pi_pub_base_ id $=85286$.

CRAFT, A. Creativity and Early Years Education. London: Continuum, 2002.

CRAFT, A. Creativity and education futures: Learning in a digital age. England: Trentham Books, 2011.

FINNISH NATIONAL AGENCY FOR EDUCATION. Finnish Education in a NutshellGrano OyMinistry of Education and Culture, , 2017. Disponível em: internal-pdf://0665306019/146428_finnish_education_ in_a_nutshell.pdf.

FUENTE, A. Human Capital and Productivity. Barcelona. Disponível em: http://www.iae.csic.es/ investigatorsMaterial/a12114115634archivoPdf97221.pdf.

GLĂVEANU, V. P. The Possible as a Field of Inquiry. Europe's Journal of Psychology, [S. I.], v. 14, n. 3, p. 519-530, 2018. DOI: https://doi.org/10.5964/ejop.v14i3.1725.

GLĂVEANU, V. P. The Possible: A Theory. Oxford, UK: Oxford University Press, 2020. 
GLĂVEANU, V. P.; BEGHETTO, R. A. The difference that makes a 'creative' difference in education. In: SRIRAMAN, B.; BEGHETTO, R. A. (org.). Creative Contradictions in Education: Cross Disciplinary Paradoxes and Perspectives. [s.I.] : Springer International Publishing, 2017. p. 37-54.

GOODMAN, N. Ways of worldmaking. Indianapolis, Indiana: Hackett Publishing, 1978.

GUIDANO, V. F. The self in process: toward a post-rationalist cognitive therapy. New York: Guilford Press, 1991.

HUANG, Li. Mind-Body Dissonance: A Catalyst to Creativity. Personality and Social Psychology Bulletin, [S. I.], v. 46, n. 5, p. 754-768, 2020. DOI: 10.1177/0146167219875145. Disponível em: https:// doi.org/10.1177/0146167219875145.

JIA, Xiaoyu; LI, Weijian; CAO, Liren. The role of metacognitive components in creative thinking. Frontiers in Psychology, [S. I.], v. 10, n. OCT, 2019. DOI: 10.3389/fpsyg.2019.02404. Disponível em: https://www.ncbi.nlm.nih.gov/pmc/articles/PMC6821789/pdf/fpsyg-10-02404.pdf.

JUNG, R.; VARTANIAN, O. The Cambridge Handbook of the Neuroscience of Creativity. Cambridge, UK: Cambridge University Press, 2018.

KARWOWSKI, M.; BARBOT, B. Creative Self-Beliefs: Their Nature, Development, and Correlates. In: KAUFMAN, J. C.; BAER, J. (org.). Current Perspectives in Social and Behavioral Sciences. Creativity and Reason in Cognitive Development . Cambridge: Cambridge University Press, 2016. p. 302-326. DOI: 10.1017/CBO9781139941969.016. Disponível em: internal-pdf://0918141989/creativeselfbeliefs-their-nature-development-.pdf.

KARWOWSKI, M.; CZERWONKA, M.; KAUFMAN, J. C. Does Intelligence Strengthen Creative Metacognition? Psychology of Aesthetics Creativity and the Arts, [S. I.], v. 14, n. 3, p. 353-360, 2020. DOI: $10.1037 / a c a 0000208$.

KARWOWSKI, M.; LEBUDA, I.; BEGHETTO, R. Creative Self-Beliefs. In: KAUFMAN, J. C.; STERNBERG, R. J. (org.). The Cambridge Handbook of Creativity. Cambridge, USA: Cambridge University Press, 2019. p. 396-417. DOI: 10.1017/9781316979839.021. Disponível em: internalpdf://83.53.41.100/Creative Self_Beliefs_Karwowski_Lebuda_Beghett.pdf.

KEGAN, R. The evolving self: problem and process in human development. Cambridge: Harvard University Press, 1982.

MINISTRY OF EDUCATION. Students Profile for the XXI century. Lisbon: Ministry of Education, 2017.

MONTUORI, A. Complexifying the Future. In: CAPRA, F.; ALLOCCA, N.; BOI, L.; GEMBILLO, F.; MONTUORI, A.; PAOLOZZI, E.; RUIZ, J. L. S. (org.). Complessità ed etica. [s.I.] : Armando Siciliano Editore, 2021. p. 58-78.

OECD. The future of education and skills: Education 2030ParisOECD Publishing, , 2018. Disponível em: http://www.oecd.org/education/2030/oecd-education-2030-position-paper.pdf.

OECD. The OECD Learning Compass 2030, 2020. Disponível em: https://www.oecd. org/education/2030-project/teaching-and-learning/learning/. 
SALICETI, F. Educate for Creativity: New Educational Strategies. Procedia - Social and Behavioral Sciences, [S. I.], v. 197, n. February, p. 1174-1178, 2015. DOI: 10.1016/j.sbspro.2015.07.374. Disponível em: http://dx.doi.org/10.1016/j.sbspro.2015.07.374.

SERDYUKOV, P. Innovation in education: what works, what doesn't, and what to do about it? Journal of Research in Innovative Teaching \& Learning, [S. I.], v. 10, n. 1, p. 4-33, 2017. DOI: 10.1108/ jrit-10-2016-0007. Disponível em: https://www.emerald.com/insight/content/doi/10.1108/JRIT-10-20160007/full/pdf?title=innovation-in-education-what-works-what-doesnt-and-what-to-do-about-it.

STIEGLER, B. Individuation et grammatisation: Quand la technique fait sens.... DocumentalisteSciences de L'information, [S. I.], v. 42, p. 354-360, 2005. DOI: 10.3917/docsi.426.0354.

STIEGLER, B. Uncontrollable societies of disaffected individuals. Nordic Journal of Aesthetics, [S. I.], v. 23, n. 44-45, p. 129-134, 2013. DOI: https://doi.org/10.7146/nja.v23i44-45.8185.

TANG, Min; HOFREITER, Sebastian; REITER-PALMON, Roni; BAI, Xinwen; MURUGAVEL, Vignesh. Creativity as a Means to Well-Being in Times of COVID-19 Pandemic: Results of a Cross-Cultural Study. Frontiers in Psychology, [S. I.], v. 12, p. 265, 2021. DOI: 10.3389/fpsyg.2021.601389. Disponível em: https://www.frontiersin.org/article/10.3389/fpsyg.2021.601389.

\section{UNESCO. Educação 2030 - Declaração de Incheon: Rumo a uma educação de qualidade} inclusiva e equitativa e à educação ao longo da vida para todosIncheon, KOUNESCO, , 2016. Disponivel em: http://www.mpsp.mp.br/portal/page/portal/cao_civel/aa_ppdeficiencia/Declaração de Incheon e Marco de Ação - Educação 2030.pdf.

VALQUARESMA, A. Challenges of contemporaneity: what course to creativity? - comprehensive exploration of the developmental role of creative self-efficacy, aesthetic judgment and schooling in creativity. 2020. University of Porto, [S. I.], 2020. Disponível em: https://hdl.handle. net/10216/131723.

VALQUARESMA, A.; COIMBRA, J. L. Lugar e funções psicológica e educacional da Criatividade no currículo implementado da educação pré-escolar e do ensino básico : Contributos de um grupo de discussão focalizada com docentes portugueses. In: CASTRO, P. A.; SÁ, S.; TEMER, A. C.; SANMAMED, M. G.; SAAVEDRA, R. A. (org.). New Trends in Qualitative Research. [s.I.] : Ludomedia, 2021. a. v. 7p. 386-395. DOI: https://doi.org/10.36367/ntqr.7.2021.386-395.

VALQUARESMA, A.; COIMBRA, J. L. Creativity, Learning and Technology: Lights and Insights for New Worldmaking Possibilities in Education. Creativity. Theories - Research - Applications, [S. I.], v. 8, n. 1, p. 38-51, 2021. b. DOI: doi:10.2478/ctra-2021-0004. Disponível em: https://doi.org/10.2478/ctra2021-0004.

VINCENT-LACRIN, S.; GONZÁLEZ-SANCHO, C.; BOUCKAERT, M.; LUCA, F.; FÉRNANDEZBARRERRA, M.; JACOTIN, G.; URGEL, J.; VIDAL, Q. Fostering Student's Creativity and Critical Thinking: What it Means in School . Paris: OECD Publishing, 2019. DOI: https://doi. org/10.1787/62212c37-en.

WEINBERG, B. A.; GALENSON, D. W. Creative Careers: The Life Cycles of Nobel Laureates in Economics. De Economist, [S. I.], p. 1-19, 2019. DOI: 10.1007/s10645-019-09339-9. Disponível em: https://doi.org/10.1007/s10645-019-09339-9. 